\title{
THE ALBANIAN COMMUNITY OUTLINE ACCORDING TO ARBEN XHAFERI
}

\author{
Ph.d Student FLAKRON BEXHETI \\ SEEU- Faculty of Contemporary Social Sciences - Political Sciences, \\ Tetovo, North Macedonia \\ Email: flakron.bexheti@hotmail.com
}

\begin{abstract}
The study aims to address Arben Xhaferi's political thought about the idea of establishing a single nation-wide association that would deal with the resolution of many open issues of Albanians spread across several states. He is aware that the non-realization of the rights of Albanians in various different areas requires an interaction of the Albanian factor, despite their division with several boundaries. Recognizing the past of his compatriots and their commitment to a single alphabet, a single standard language, an Albanian school and many other areas of life related to cultural and identity issues, Arben Xhaferi designed a nationwide program called, "An Outline of the Common Prosperity." According to him, this project that deals with the issues of identity, unification of national standards, democracy, economy, education, gender equality, secularism, human rights, judiciary, sport, and youth, will not be against the interests of the states where Albanians live; on the contrary, it will benefit them, because it is about advancing the rights of their own citizens. He justifies this project as something very positive, taking the example of some other states and nations that have already achieved results in this regard. On this occasion, he mentions the Francophone or the Commonwealth project, founded by civilized nations. The functioning and collaboration of Albanians, according to these models, will make it easier for them to utilize all their intellectual and human capacities.
\end{abstract}

Key words: prosperity, organization, nation-wide, right, culture, education

The Albanian community outline according to Arben Xhaferi 
Following a great deal of analyses, debates and discussions broadcast in nationwide and international media on the Albanian, as well as regional and international issues, by the end of 2008, Arben Xhaferi appeared to the public with the idea of establishing a single national association that would deal with the Albanian issue. This new approach of his to consolidating and strengthening the nation-wide spirit was not well received by many circles of the antiAlbanian sentiment, and was also seen as a tendency for the formation of ethnic Albania. It is a fact that his idea is a continuation of the spirit of the Renaissance representatives, who considered that the fate of a divided and separated nation was in its unification, but of a variant that corresponds to the conditions of time and limited opportunities to achieve that goal. If Sami Frashëri, in his work "Shqipëria ç'ka qenë, ç'është dhe ç'do të bëhet", approaches the history of the destiny of the nation, in his time, and how it should be in the future, Arben Xhaferi, recognizing the past, and the present, when the nation operates in several states, with his idea called "An Outline of the Common Prosperity", aimed at solving the problems of common interest and coordinating the actions of all Albanians in many spheres of life, such as:

- Issues of identity;

- Unification of national standards;

- Democracy

- Economy

- Education

- Gender equality

- Secularism

- The judiciary

- Sports

- Interaction

- Youth $^{1}$

The beautiful Albanian term, "Mbrothësi" (Prosperity), which was also favoured by the renaissance activists of the time, referred to the well-being and prosperity of the nation, leading to their future development, although they may live in different states. According to him, this way of moving forward by affirming shared ethnic, cultural, educational, economic values, etc., is feasible and possible, despite the activity of these areas that are unlikely to be realized separately. Perhaps, the to-date experience shows that a normal and all-pervasive development cannot be successful when it is so partitioned. Furthermore, with regard to Albanians abroad (even outside Kosovo, if it also counts as a state for Albanians), a normal development in the spheres he mentions is not even possible, despite their efforts to achieve their full rights through

\footnotetext{
${ }^{1}$ Arben Xhaferi, "Skicë për mbrothësinë e përbashkët", Tetovë, 1.10.2008, published in his Book 01 of his collection of volumes, p. 143
} 
ISSN 2661-2666( Online) International Scientific Journal “Monte" DOI: $10.33807 /$ monte/3/201912497 ISSN 2661-264X (Print)

the political parties operating within those states. Speaking of the objectives and activities, he says, "Prosperity is characterized as an international organization that seeks to solve the problems faced by widespread national communities in many countries." 2 Arben gives the definition of this Institution as follows: "The Common Prosperity is a voluntary non-political organization".

This project will include the states, namely the Albanian communities living in different countries of the world" ${ }^{3}$. Following the definition, the author of this project also highlights the goals of the establishment, such as common interests, affirmation of democracy, affirmation of human rights, good governance, rule of law, individual rights, equality, free trade and peace in the world. With regard to this institution, Arben also envisages the way of functioning through certain bodies. The leadership will be elected by the members of the organization and will be depoliticized, preventing various party influences. The chief of the presidency will be the Secretary-General, who will have executive authority, following the example of the Commonwealth, where the leadership is formally or symbolically held by the Queen. A similar way can be practiced with this organization, where the Albanian royal court may have a symbolic leadership role. As for the membership, some important documents have been foreseen.

The leadership structure, headed by the Secretary, should have its headquarters in Tirana, while the branches of "The Prosperity" will extend to other centres where Albanians live. The Secretary, in cooperation with officials of different levels from among the Albanians, organizes meetings of interest for the nation, where different political, economic and professional issues will be dealt with in different fields and designs programs for the realization of projects that will help overcome obstacles that may arise in Albanian societies. The sections of the secretariat shall be headed by the Secretary General and his two deputies. The term of office of the Secretary shall be four years, with the right to be re-elected. Part of the "prosperity" will be other secondary subjects related to educational, academic, sports, judicial, legal activities, including other parliamentary institutions.

This idea of Arben Xhaferi, as he himself concludes, is bold, as well as unrealizable, but much needed, at a time when the tissue of a divided nation in several states is constantly weakening, headed towards the path of deforming the national being. This nationwide project of Arben, inspired for sure by the historical past and the patriotic activity of the renaissance, despite all the difficulties and obstacles that may come from obstructive foreign circles with anti-Albanian sentiment, is feasible, since its only aim is the unity of the nation in terms of consolidating

\footnotetext{
${ }^{2}$ Arben Xhaferi, "Skicë për mbrothësinë e përbashkët", Tetovo, 1.10.2008, published in his Book 01 of the collection of volumes, p. 143

${ }^{3}$ Ibid, p. 142
} 
ISSN 2661-2666( Online) International Scientific Journal “Monte" DOI: $10.33807 /$ monte/3/201912497 ISSN 2661-264X (Print)

national awareness of the preservation and cultivation of ethno-cultural values, which have become so fragmented.

Aware of the allegations that could be addressed to him for his nationalist ideas after the design of this project, being even considered as an instigator of endangering peace in the region, Arben Xhaferi, gives examples, at the beginning of this paper, of various cases where nationalism of the other is also criticized by the nationalist position. He illustrates this phenomenon with the attitudes of Russia and China, powers that have opposed the independence of Kosovo, even stating, "In Kosovo their national interest is protected, while Kosovars would be declared as nationalists if they claimed that in Kosovo, the interests of Albanians are protected". ${ }^{4}$

With these examples, he justifies the thesis that nationalism is anathematized as a war incendiary everywhere in the world, despite affirmative statements about nationalism as a protector of ethnic interests, especially of the small peoples who oppose the occupying ruler. For Arben Xhaferi, any resistance in favour of national liberation and the protection of ethnic interests should not be considered as war-inciting; therefore, he stresses that Europe is the birthplace of nationalism, which now views this phenomenon as threatening to peace in the region and beyond. He also justifies this view with various examples, mentioning many states of European civilization that overcame conflicts after the final resolution of their open ethnic issues. On this occasion, he mentions the American sociologist Benedict Anderson, who rightly states that, "Nationalism emerged on the European historical scene in the 16th century, when the peoples of Europe lost faith in their sacred books, namely in the sacred "truths" that turned out to be false." ${ }^{5}$ The collapse of this belief in religion had to be sought elsewhere, and nationalism was invented instead, that is, there was this movement or transfer from the divine to the human.

Arben Xhaferi performed all of these analytical approaches in order to justify his "Prosperity" project towards the others, and prove that this program only serves to protect the Albanian national interest without harming anyone.

For the affirmative role, when positive nationalism preserves the nation and national being, he takes the example of France, where nationalism had an emancipating and liberating role, whereupon they formed their state, which they identified with the nation. If heterogeneous or multi-ethnic societies did not subject to the rule of law in order to guarantee full equal rights, they would be disbanded, as was the case with the Ottoman Empire, Austro-Hungary, Russia,

\footnotetext{
${ }^{4}$ Arben Xhaferi, "Skicë për mbrothësinë e përbashkët", Tetovo, 1.10.2008, published in his Book 01 of the collection of volumes, p. 138

${ }^{5}$ Arben Xhaferi, "Skicë për mbrothësinë e përbashkët", Tetovo, 1.10.2008, published in his Book 01 of the collection of volumes, p. 143
} 
ISSN 2661-2666( Online) International Scientific Journal “Monte" DOI: $10.33807 /$ monte/3/201912497 ISSN 2661-264X (Print)

Yugoslavia, Czechoslovakia, etc. On these issues relating to nationalism, he also quotes a Swiss sociologist, Urs Alterrmat, who rightly states in his book, "European Ethno-Nationalism", that nationalism in Europe had two types of contradictory functions:

- it influenced the disintegration of states, empires, multiethnic social formations, such as AustroHungary, and

- it fostered the creation of small feudal states in a national state of people of the same origin, such as Germans or Italians.

The fragmentation of the Albanian tissue and the division into several states, after the dissolution of the Ottoman Empire, made it impossible for them to develop normally in terms of the common interest of the spheres mentioned above. Having considered this stagnation, not because of the Albanians themselves, Xhaferi came up with this platform, which is a novelty in these areas, as it is indispensable. This way of organization, in his opinion, can be accomplished through goodwill and the need for a national interest. Albanians in Albania, he says, have no restriction of national rights; Albanians in Kosovo also have freedom but not sovereignty, for the time being, because they share their sovereignty with the international factor. In Macedonia, as it can be seen, Albanians will still have to fight for their rights for a long time, whereas in the Preshevo Valley and Montenegro it seems that they will remain national minorities. As the situation is today, Albanians find it difficult to realize their goals. That is why he thinks that there is a need to find other ways to overcome obstacles that objectively stifle the economic, cultural and educational development of the Albanians as well as their security. This way of organization, which enables mechanisms that guarantee safe development in these areas, is not harmful; rather, he says, nations that have created their own states and have managed, in time, to practice this way of their nation's prosperity, though they have achieved it in an easier way, have never been able to be hindered by any means. Bloody wars have been fought for these achievements in many countries around the world. For such an organization, he mentions the example of the Francophone project, or the Commonwealth (Cromwell), founded by civilized peoples, such as the French or the British. "The first project establishes cohesive relations with different peoples on the basis of expanding the use of the French language, while the second one on the basis of common welfare." ${ }^{6}$ According to these models and the like, Albanians, in his opinion, would be able to better utilize all human capacities and resources, which they cannot do in a situation of division and segregation as they are currently in, because Albanian societies are not standardized, and in such circumstances, the values of other peoples penetrate very easily, a fact that has been

\footnotetext{
${ }^{6}$ Arben Xhaferi, "Skicë për mbrothësinë e përbashkët", Tetovo, 1.10.2008, published in his Book 01 of the collection of volumes, p.141
} 
ISSN 2661-2666( Online) International Scientific Journal “Monte" DOI: $10.33807 /$ monte/3/201912497 ISSN 2661-264X (Print)

hitherto proven that "without standardization, no value can be protected, especially those concerning national identity. ${ }^{7}$

\section{Conclusions:}

- Arben Xhaferi's idea for this project aims to protect the national interests of Albanians and to coordinate their actions in the fields related to cultural, educational, economic and scientific values.

- Arben Xhaferi stated that the countries, in which Albanians live, apart from Albania, never engaged in this direction, in order to provide them with normal development in the areas of common identity interest.

-With the formation of this association of national interest, he thinks that Albanians will solve their own open issues that they have not been able to solve in the countries where they live divided among themselves.

-With regard to this initiative, he also referred to the example of the Commonwealth and the Francophone project, through which the common welfare is developed and the expansion of the use of the French language all over the world.

-This way of organizing which enables mechanisms to ensure safe development in these areas, is not harmful to the others by any means, in his opinion.

- Through this model of organization, according to him, Albanians would utilize all intellectual capacities that could not come to surface in the countries where they currently live.

\footnotetext{
${ }^{7}$ Arben Xhaferi, "Skicë për mbrothësinë e përbashkët", Tetovo, 1.10.2008, published in his Book 01 of the collection of volumes, p. 143
} 
ISSN 2661-2666( Online) International Scientific Journal “Monte” DOI:10.33807/monte/3/201912497 ISSN 2661-264X (Print)

\section{References:}

Arbën Xhaferi, Kombi, Identiteti, Sheti, Vepra 01, Tiranë 2017

Arbën Xhaferi, Kauza shqiptare në Maqedoni, Vepra 02, Tiranë 2017

Rudina Xhunga, 12 porositë e Arbën Xhaferit, Tiranë 2012

Enver Rubelli, Në Tetovë, në kërkim të kuptimit 2008 